\title{
Determination of In Vitro Activity of Linezolid in Resistance Gram-positive Bacteria by E-Test Method
}

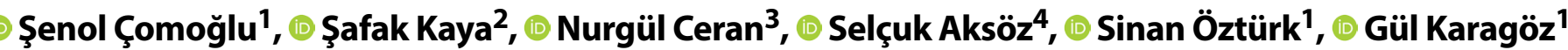

${ }^{1}$ Department of Infectious Diseases Clinic, Health Sciences University, Umraniye Training and Research Hospital, Istanbul, Turkey ${ }^{2}$ Department of Infectious Diseases Clinic, Health Sciences University, Gazi Yasargil Training and Research Hospital, Diyarbakir, Turkey ${ }^{3}$ Department of Infectious Diseases Clinic, Health Sciences University, Haydarpasa Numune Training and Research Hospital, Istanbul ${ }^{4}$ Department of Infectious Diseases Clinic, Adiyaman Training and Research Hospital, Adiyaman, Turkey

\begin{abstract}
Introduction: The incidence of infections caused by multidrug-resistant Gram-positive bacteria is increasing in the past years. The pathogens such as glycopeptid-resistant enterococci, methicillin-resistant Staphylococcus aureus (MRSA), and coagulase-negative staphylococci (CoNS) have emerged widely and they contribute an increase. The treatment of the patients infected with the multidrug-resistant pathogens is extremely difficult. The aim of this study was to determine in vitro susceptibility of vancomycin-resistant enterococci (VRE) and staphylococci against linezolid that may provide new alternative to treat.

Methods: A total of 80 isolates of staphylococci (30 MRSA, 30 MSSA, and 20 Methicillin-resistant coagulase-negative staphylococci [MRCoNS]) obtained from various clinical specimens and 20 VRE isolates recovered from blood and rectal swab specimens were sent to our microbiology laboratory. Linezolid susceptibility was determined by disc diffusion methods and E-test for all isolates. In addition, for all isolates, sensitivity to other antibacterials was detected by Kirby-Bauer disc diffusion method according to guidelines established by the Clinical and Laboratory Standards Institute.

Results: The results showed that all strains were fully susceptible to linezolid (minimal inhibitory concentration [MIC] $\leq 2$ $\mu \mathrm{G} / \mathrm{ml}$ ). The linezolid effectiveness is not different between the MRSA and MSSA strains. MICs were changed for MRSA from 0.018 to $2 \mu \mathrm{g} / \mathrm{ml}$, MSSA from 0.25 to $1.5 \mu \mathrm{g} / \mathrm{ml}$, and MRCoNS from 0.19 to $1 \mu \mathrm{g} / \mathrm{ml}$. MICs were changed from 0.38 to $2 \mu \mathrm{g} /$ $\mathrm{ml}$ for VRE strains.

Discussion and Conclusion: As a result of the present study, it was decided that linezolid appears to be a good alternative in the treatment of infections caused by Gram-positive bacteria, especially those resistant to glycopeptides or with reduced sensitivity.

Keywords: E-test; in vitro activity; linezolid; resistance.
\end{abstract}

$\mathrm{T}$ he course of infectious diseases has changed greatly since the beginning of antibiotic age in the 1940s. Previously, multiple antibiotic resistance and treatment problems seen with Gram-negative bacteria were also observed in the treatment of Gram-positive bacterial infections in later years
[1]. In addition to the treatment difficulty caused by multiple antibiotic resistance in infections caused by methicillin-resistant Staphylococcus aureus (MRSA) strains, these strains can cause nosocomial epidemics, making MRSA infections a serious health problem all over the world.

Correspondence (iletişim): Şenol Çomoğlu, M.D. Saglik Bilimleri Universitesi, Umraniye Egitim Arastirma Hastanesi,

Enfeksiyon Hastaliklari Klinigi, Istanbul, Turkey

Phone (Telefon): +90 5325063658 E-mail (E-posta): sencomoglu@gmail.com

Submitted Date (Başvuru Tarihi): 04.06.2018 Accepted Date (Kabul Tarihi): 03.08.2018

Copyright 2019 Haydarpaşa Numune Medical Journal

This is an open access article under the CC BY-NC license (http://creativecommons.org/licenses/by-nc/4.0/). 
These epidemics bring with it a huge financial burden ${ }^{[2-4]}$. In 2002, the first vancomycin-resistant Staphylococcus aureus (VRSA) strain was isolated in the US and was followed by new ones. Frequent use of vancomycin in severe infections caused a decreased sensitivity to and resistance to vancomycin ${ }^{[5]}$.

Glycopeptide resistance has increased significantly in recent years. In our hospital, an increase in the number of patients with or without glycopeptide-resistant enterococci (GRE) is being observed ${ }^{[6]}$. As a result, varying resistance patterns require alternative treatment options for vancomycin. The latest antibiotics developed to treat resistant Gram-positive microorganisms include oxazolidinones. Oxazolidinones are new synthetic antimicrobials found in 1987, and the first member of this group is linezolid [7].

The aim of our study is to determine the in vitro activity and minimal inhibitory concentration (MIC) of linezolid, which was introduced in our country in 2005 against infections caused by staphylococci and enterococci isolated from blood cultures and various clinical samples. We tried to determine whether linezolid activity is different for methicillin-resistant and sensitive strains.

\section{Materials and Methods}

This study is a prospective study that was approved by the Ethics Committee of Haydarpaşa Numune Education and Research Hospital. A total of 100 strains, including 30 MRSA, 30 MSSA, 20 methicillin-resistant coagulasenegative staphylococci (MRCoNS), and 20 vancomycinresistant enterococci (VRE) strains, isolated from various clinical samples were studied. Fifteen VRE strains were isolated from blood cultures and 5 from fecal swabs. The samples from which these strains were isolated are shown in Table 1. Isolated strains were identified, passaged in stock culture media, and stored at $-70^{\circ} \mathrm{C}$ until the study was performed.

\section{Identification of the Bacteria}

\section{Staphylococci}

The strains grown in hemoculture were passaged into the blood agar medium, and their pure cultures were obtained and stained with gram dye. Morphology of bacterial colonies and hemolysis of the strains were evaluated. Catalase-positive strains were tested for the presence of coagulase.

Methicillin resistance was evaluated in all staphylococcus strains. For this purpose, Müller-Hinton agar with $2 \% \mathrm{NaCl}$ was used. It was prepared from the 24-h culture of the staphylococci to be investigated in suspension with McFarland 0.5 turbidity in the broth.

This suspension was cultured on the medium. Standard 1 $\mu \mathrm{g}$ oxacillin discs were used to determine the methicillin resistance. After $24 \mathrm{~h}$ of incubation at $35^{\circ} \mathrm{C}$, the inhibition zones were measured and evaluated according to the Clinical and Laboratory Standards Institute (CLSI) criteria. If diameters of oxacillin zone were $\geq 13 \mathrm{~mm}, 11-12 \mathrm{~mm}$, and $\leq$, then $S$. aureus was considered to be susceptible, less susceptible, and resistant to oxacillin, while MRSA with inhibition zones of $\geq 18$ and $\leq 17 \mathrm{~mm}$ was deemed to be susceptible and resistant to oxacillin, respectively. In addition, susceptibilities of all strains were determined by Kirby-Bauer disk diffusion method against antibiotics as indicated in the CLSI guidelines.

\section{Enterococci}

If the catalase test was negative for the bacteria isolated from the culture samples, bacterial growth in $6.5 \% \mathrm{NaCl}$ and PYR test was applied. The strains grown in $6.5 \% \mathrm{NaCl}$ and yield PYR test positivity were evaluated as enterococci.

\section{$6.5 \% \mathrm{NaCl}$ Assay}

For this assay, 2-3 colonies of bacteria were seeded on brain heart infusion (BHI) broth containing $6.5 \% \mathrm{NaCl}$. The

Table 1. Microorganisms isolated material

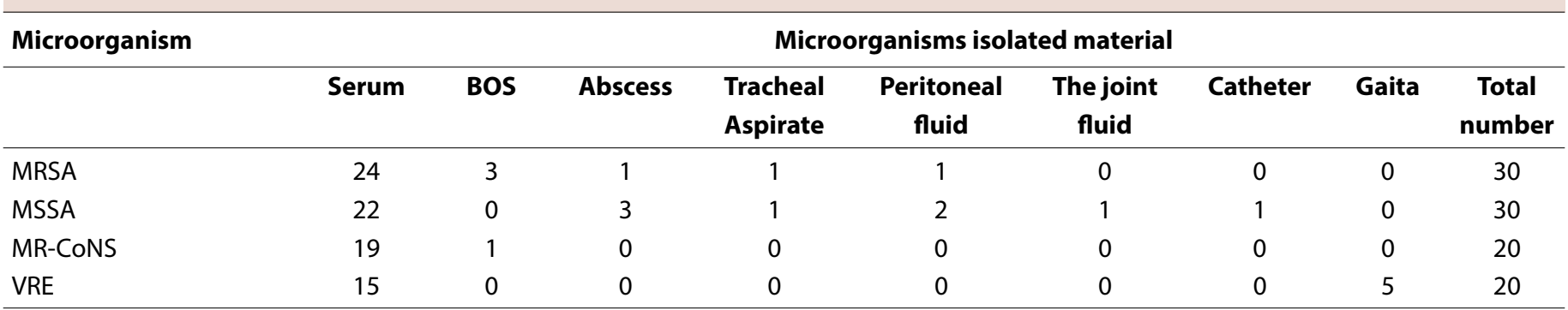

MRSA: Methicillin-resistant Staphylococcus aureus; MSSA: Methicillin-Susceptible Staphylococcus aureus; MR-CoNS: Methicillin-resistant coagulase-negative staphylococci ; VRE: Vancomycin-resistant enterococci. 
development of turbidity as a result of bacterial growth was considered test positivity.

Vancomycin powder was added onto the $\mathrm{BHI}$ agar to determine vancomycin resistance with a vancomycin concentration of $6 \mathrm{mg} / \mathrm{l}$. Enterococci strains were cultivated on this medium at decreasing dilutions. At the end of incubation, the strains were evaluated as VRE. Bile esculin agar was used for the isolation of VREs from feces. The strains were immunized with $\mathrm{BHI}$ agar (VRE agar) containing vancomycin $6 \mu \mathrm{g} / \mathrm{ml}$, and vancomycin resistance was determined.

Kirby-Bauer disk diffusion method was used for antibiotic susceptibility of the strains. Vancomycin, penicillin, ampicillin, cefazolin, erythromycin, levofloxacin, and linezolid discs were used. ATCC 25923 strain for staphylococci and ATCC 29212 strain for enterococci were used as control strains.

\section{Results}

In our study, the rates of resistance in MRSA strains determined by disk diffusion method were $100 \%$ for erythromycin, 57\% for clindamycin, 27\% for fusidic acid, 30\% for sulfamethoxazole, $93 \%$ for ciprofloxacin, $90 \%$ for levofloxacin, and $100 \%$ for gentamicin.

In the MSSA strains, resistance rates were found to be as indicated in parentheses: Erythromycin (30\%), clindamycin (7\%), fusidic acid (14\%), SXT (17\%), ciprofloxacin (10\%), levofloxacin (10\%), gentamicin (17\%), penicillin and ampicillin resistance (100\%), SAM (20\%), and cefazolin (7\%).

Resistance rates in MRCoNS strains were determined as follows: Erythromycin (60\%), clindamycin (40\%), fusidic acid (50\%), SXT (60\%), ciprofloxacin (90\%), levofloxacin (70\%), and gentamicin (50\%).

\section{Linezolid Results}

Linezolid MICs were as follows: MRSAs $(0.018-2 \mu \mathrm{g} / \mathrm{ml})$, MSSAs $(0.25-1.5 \mu \mathrm{g} / \mathrm{ml})$, MRCoNS $(0.19-1 \mu \mathrm{g} / \mathrm{ml})$, and VREs (0.38-2 $\mu \mathrm{g} / \mathrm{ml}$ ) (Table 2 ).

\section{Discussion}

The incidence of multiple-resistant Gram-positive bacterial infections is increasing, and they complicate the treatment of nosocomial infections ${ }^{[1]}$. The high morbidity and mortality of MRSA infections led to the monitorization of the prevalence of multiple antibiotic-resistant staphylococci, mainly MRSA. Methicillin resistance rates have gradually increased within years, and in some centers, it reached up to $70 \%{ }^{[8]}$.

Due to methicillin resistance in Staphylococci, glycopeptide antibiotics are most effective, and reliable alternatives in cases seriously infected with these bacteria. Vancomycin is the leading glycopeptide antibiotic. Vancomycin can be widely used in empirical treatment of catheter-related infections in hemodialysis patients, as a prophylactic antibiotic in Gram-positive infections in patients who are receiving peritoneal dialysis, and in cardiovascular surgery patients who developed nosocomial infections due to MRSA. Due to its widespread use, the problem of resistance has started to emerge. While $S$. aureus has been found to have decreased susceptibility to vancomycin, since 2002, S. aureus strains have been reported to have high resistance to vancomycin (MIC $>32 \mu \mathrm{g} / \mathrm{ml})^{[9,10]}$.

S. aureus strains with decreased susceptibility to glycopeptides (MIC 8-16-16 $\mu \mathrm{g} / \mathrm{ml}$ ) were first reported from Japan and then from the US, Europe, and Korea. These strains were found in patients who had been using vancomycin for long term without any recovery ${ }^{[1,11]}$.

Teicoplanin, another glycopeptide preparation, has advantages such as ease of use and lesser side effects than vancomycin. Therefore, it was started to be used as the first option instead of vancomycin. Teicoplanin resistance develops more easily than vancomycin and has higher MICs.

Strains are susceptible to vancomycin, but decreased sensitivity to teicoplanin has been reported at an increased frequency ${ }^{[12,13]}$. Derbentli et al. ${ }^{[14]}$ did not detect resistance to vancomycin in staphylococci strains, but a decreased rate of susceptibility was reported in $0.3 \%$, and $0.8 \%$ of MRSA strains to vancomycin and teicoplanin, respectively.

Table 2. Linezolid MIC values in microorganisms

\begin{tabular}{|c|c|c|c|c|c|c|c|c|c|c|c|c|c|c|}
\hline $\begin{array}{l}\text { Microorganism } \\
\mathrm{n}\end{array}$ & \multicolumn{14}{|c|}{ MIC values $(\mu \mathrm{g} / \mathrm{ml})$} \\
\hline MRSA & 1 & - & 2 & 9 & 6 & 4 & 3 & 1 & 2 & - & - & 1 & 1 & 30 \\
\hline MRCoNS & - & - & 2 & 5 & 10 & 1 & 1 & 1 & - & - & - & - & - & 20 \\
\hline VRE & 6 & 3 & 3 & 2 & 3 & 3 & - & - & - & - & - & - & - & 20 \\
\hline
\end{tabular}

MIC: Minimal inhibitory concentration; VRE: Vancomycin-resistant enterococci; MRCoNS: Methicillin-resistant coagulase-negative staphylococci. 
The corresponding rates were reported as $0.4 \%$ and $1.3 \%$ in MRCoNS strains. In our study, vancomycin-resistant MRSA and MRCoNS strains were not detected.

As is seen herein, glycopeptide resistance is not seen as a common problem for our country. However, it is wise to seek alternative treatment options with non-glycopeptide antibiotics, especially, in patients treated with mild-tomoderate infections caused by MRSA. In such cases, susceptibility to other antibiotic groups such as fusidic acid, SXT, clindamycin, erythromycin, and quinolones is gaining importance. Fusidic acid has been in use beginning from 1962, and since 1998, it has an oral form in our country. Especially, fusidic acid activity in $\beta$-lactam antibiotic-resistant staphylococcal strains increased the interest in this antibiotic. Due to the availability of only its oral form, it has been found to be of use, especially, in the outpatient treatment of MRSA infections ${ }^{[15]}$. In our study, fusidic acid sensitivity was found to be $73 \%$ in MRSAs, $86 \%$ in MSSAs, and $50 \%$ in MRCoNS. When the studies conducted on fusidic acid in our country are examined, in a study by Şengöz et al. ${ }^{[16]}$ performed with fusidic acid, the rates of resistance in MRSAs (9\%), MSSAs (1\%), MRCoNS (33\%), and MSCNS $(21 \%)$ were detected as indicated. Doğan et al. ${ }^{[17]}$ reported that fusidic acid resistance was $11 \%$ in MSCoNS and $39 \%$ in MRCoNS strains isolated from blood samples. In our study, fusidic acid resistance was found to be higher in MRCoNS compared to other studies, but the susceptibility rates in MRSA and MSSAs were parallel to other studies.

These findings suggest that fusidic acid is an alternative antibiotic for the treatment of infections caused by methicillin-resistant staphylococci.

Another $\beta$-lactam antibiotic used in resistant staphylococci is SXT. Şengöz et al. ${ }^{[16]}$ showed that SXT sensitivity was $91 \%$ in MRSA, $95 \%$ in MSSA, 64\% in MSCoNS, and 62\% in MRCoNS strains. In another study, SXT sensitivity was found to be $92 \%$ in MRSAs and $20 \%$ in MRCoNS. ${ }^{[18]}$ In a study reported from India, SXT resistance in MRSA strains was found to be $63.2 \% .{ }^{[19]}$ In our study, SXT sensitivity was found to be $70 \%$ in MRSAs, $83 \%$ in MSSAs, and $40 \%$ in MRCoNSs.

As seen in different studies, the sensitivity of SXT in staphylococci varies from center to center. Therefore, SXT is an antibiotic that can be used as an alternative to the geographical region where the infection develops. In our study area, it is considered to be an empirical antibiotic, especially in MSSA infections.

Quinolones are not among $\beta$-lactam group antibiotics, and some of their members are effective on staphylococci. In our study, resistance rates in MRSAs to ciprofloxacin and levofloxacin were $93 \%$ and $90 \%$, respectively. In MRCoNS, rates of resistance to ciprofloxacin and levofloxacin were similar (70\%). In the study conducted by Şengöz et al. ${ }^{[16]}$ with MSSAs, the resistance to ofloxacin was $9 \%$, while it was reported to be $84 \%$ in MRSAs and $67 \%$ in MRCoNSs. As seen here, resistance rates of quinolones in methicillin-resistant staphylococci are quite high, so theay are not thought to be an alternative to empirical therapy in the treatment of infections with methicillin-resistant staphylococci.

In our study, erythromycin-sensitive strains were not detected in MRSAs, while erythromycin resistance was 30\% in MSSAs and $60 \%$ in MRCoNSs. Rates of erythromycin resistance in MRSA strains in different studies from Turkey have been reported as $58.6 \%, 71 \%, 62 \%, 40.6 \%$, and $75.6 \%$, while, for MRCoNSs, these rates were indicated as $77 \%$ and $61 \%$, respectively ${ }^{[12,16]}$. In general, erythromycin is not considered as an alternative antibiotic for the treatment of methicillin-resistant staphylococci. Clindamycin is an alternative antibiotic for staphylococcal infections. In our study, clindamycin resistance was found in $57 \%$ of MRSA, $7 \%$ of MSSA, and $40 \%$ of MRCoNS strains. Clindamycin resistance has been reported as $39-54 \%$ in various studies performed in our country ${ }^{[12,16]}$.

In MRSAs, there is no susceptible strain against penicillin. In some studies, susceptible strains are reported to be negligible in MSSAs. In our study, in MRSA, MSSA, and MRCoNS resistance to penicillin, ampicillin was $100 \%$, while cefazolin resistance was $100 \%$ in MRSA and MRCoNS and $7 \%$ in MSSAs. Sulbactam-ampicillin resistance was found to be $100 \%$ in MRSA and MRCoNS and $20 \%$ in MSSA strains. In the study of Kanan et al. [20], penicillin resistance was reported in $94 \%$ of MSSA and $100 \%$ in MRSA strains. As seen here, penicillin and ampicillin are not alternative antibiotics in the treatment of staphylococcal infections.

Enterococci have an important place among agents of nosocomial infections [21]. Due to known intrinsic resistance of many enterococci to many antimicrobial agents, the number of antibiotics that can be used in the treatment of these agents is limited. The main antibiotics used in the treatment of enterococcal infections are penicillins, aminoglycosides, and glycopeptides [22,23].

In recent years, there has been a problem in the treatment of enterococci due to the development of resistance to these antibiotics. VRE strains detected in enterococci in many countries have become widespread in our country in recent years. According to $C D C$ data, a 25 -fold increase in the prevalence of GRE between 1989 and 1993 was reported ${ }^{[24]}$. Although Enterococcus fecalis is 4 times more 
frequently encountered than Enterococcus faecium as an agent of infection, E. faecium is responsible for most GRE attacks. Between 1995 and 1997, vancomycin-resistant $E$. fecalis was found between $1.3 \%$ and $12.3 \%$ of the patients, while the incidence of vancomycin resistance in E. faecium strains increased from $28 \%$ to $52 \%{ }^{[25]}$.

In a study performed with the participation of 42 centers from 16 countries in $2004,5.3 \%$ of a total of 719 Enterococcus strains were found to be resistant to vancomycin ${ }^{[26]}$. In our study, 15 of 20 VRE strains were isolated from clinical specimens and 5 of them from stool as a result of VRE surveillance. Linezolid sensitivity was found to be $100 \%$.

The first member of the oxazolidinone group is linezolid. Due to their different mechanisms of action, they do not show cross-resistance with other antibiotics. In vitro linezolid resistance is difficult to develop. Development of resistance is typically due to a single nucleotide change in genes encoding $23 \mathrm{~S}$ ribosomal RNA. In a study conducted on 3770 Gram-positive strains with the participation of 25 hospitals in England in 2000, linezolid MIC was determined in strains of S. aureus, E. fecalis, and Streptococcus pneumoniae, and for all three bacterial strains, the MIC of linezolid was detected in the range of 1-4 $\mathrm{g} / \mathrm{l}$. In the same study, while $4 \%$ of the strains were resistant to vancomycin, any linezolid-resistant strain was not detected ${ }^{[27]}$. In comparative studies with teicoplanin in the treatment of suspected and proven Gram-positive infections, linezolid was found to be more effective than teicoplanin in different disease categories ${ }^{[28]}$.

A limited number of studies have been performed with linezolid in Turkey. Dizbay et al. ${ }^{[13]}$ investigated linezolid sensitivity in 120 MRSA strains by disk diffusion method and no resistant strain was detected. In the study of Kanan et al., ${ }^{[20]}$ the MIC ranges of linezolid were $1-4 \mu \mathrm{g} / \mathrm{ml}$ in MRSA, 0.5-2 $\mu \mathrm{g} / \mathrm{ml}$ in MRCoNS $0.25-1 \mu \mathrm{g} / \mathrm{ml}, 1-2 \mu \mathrm{g} / \mathrm{ml}$ in E. fecalis, and $1-4 \mu \mathrm{g} / \mathrm{ml}$ in E. faecium Ertem et al. ${ }^{[29]}$ did not report linezolid resistance between 2008 and 2009 in 120 hospital-acquired staphylococci strains. Ağalar et al. ${ }^{[30]}$ found linezolid resistance as $3 \%$ in 276 staphylococci strains resistant to methicillin. In their study of 100 MRSA strains, Efe et al. ${ }^{[31]}$ could not detect any resistance to linezolid. Cesur et al. ${ }^{[32]}$ did not report resistant to linezolid, vancomycin, and teicoplanin in none of the 260 MRSA strains isolated from clinical specimens of patients hospitalized in ICUs of hospitals in seven cities of Turkey. In our study, the ranges of MIC for linezolid were determined in MRSA $(0.018-2.0 \mu \mathrm{g} / \mathrm{ml})$, MSSA $(0.12-1.5-1 \mu \mathrm{g} / \mathrm{ml})$, MRNNS $(0.19-10.0 \mu \mathrm{g} / \mathrm{ml})$, and VREs $(2-0.38 \mu \mathrm{g} / \mathrm{ml})$ as indicated.
As a result of all studies, it has been observed that linezolid is an important alternative in the treatment of resistant Gram-positive bacterial infections. Although the development of resistance to linezolid is not a problem at present, minimization of the development of resistance for the future should be targeted. To that end, it has been thought that rational use of antibiotics, cooperation between clinics, and regular surveillance are necessary.

Ethics Committee Approval: This study is a prospective study that was approved by the Ethics Committee of Haydarpaşa Numune Education and Research Hospital.

Peer-review: Externally peer-reviewed.

Authorship Contributions: Concept: S.C., N.C.; Design: S.K., S.A.; Data Collection or Processing: S.C., N.C.; Analysis or Interpretation: S.C., N.C., S.K.; Literature Search: S.C., S.K., G.K., S.Ö.; Writing: S.C.

Conflict of Interest: None declared.

Financial Disclosure: The authors declared that this study received no financial support.

\section{References}

1. Ulusoy S. Gram-pozitif etkinliği olan antibiyotikler. In: Ulusoy S, Usluer G, Ünal S, editors. Önemli ve sorunlu gram pozitif bakteri infeksiyonları'nda. Ankara: Bilimsel Tıp Yayınevi; 2004. p.353-66.

2. Kloss WE, Schleifer KH. Staphylococcus. In: Sneath PH, Mair NS, Sharpe ME, Hol JG editors. Bergery's Manuel of Systematic Bacteriology. Volume: II. Baltimore: Williams-Wilkins; 1986. p.1013-35.

3. Ünal S. Akhan S. Stafilokok infeksiyonları. In: Topçu AW, Söyletir G. Doğanay M, editors. Infeksiyon Hastalıkları Kitabı. 1st edition. İstanbul: Nobel Tıp Kitabevleri; 1996. p.773-81.

4. Archer GL, Staphylococcus epidermidis and other coagulasenegative staphylococci. In: Mandell G, Bennet J E. Dolin R, editors. Principles and Practice of Infectious Disease. 5th edition. New York: Churchill Livingstone; 1990.

5. Chang S, Sievert DM, Hageman JC, Boulton ML, Tenover FC, Downes FP, et al; Vancomycin-Resistant Staphyloccocus aureus Investigate Team. Infection with vancomycin-resistant Staphylococcus aureus containing the vanA resistance gene. N Eng J Med 2003;348:1342-7. [CrossRef]

6. Şardan YÇ. Enterokoklarda direnç sorunu. Yeni ve Yeniden Gündeme Gelen İnfeksiyonlar. Ankara. Bilimsel Tıp Yayınevi: 2004. p.10-6.

7. Küçükbayrak $A$, Özdemir D. Two new protein synthesis inhibitors: Linezolid and streptogramins (quinupristin/dalfoprustin). Turkish Journal of Infection 2006:20:145-51.

8. Gonlugur U, Akkurt I, Ozdemir L, Bakici MZ, Icagasioglu S, Gultekin F. Antibiotic susceptibility patterns of respiratory isolates of Staphylococcus aureus in a Turkish university hospital. Acra Microbiologica Polonica 2003;52:142-8.

9. Livermore DM. Antibiotic resistance in staphylococci. Int J An- 
timicrob Agents 2000;16:S3-10. [CrossRef]

10. Şengül D. Antimicrobial Resistance in Staphyloccocci. Turkey Map 2003-2004. Ankem Derg 2005;19:54-60.

11. Clinical and Laboratory Standards Institute (CLSI). In: Başustaoğlu A, Gülay Z, Köksal İ, Özinel MA, Söyletir G, Sümerkan B, translation editors. Antimikrobik Duyarlılık Testleri için Uygulama Stabdartları; Onyedinci Bilgi Eki. Ankara: Bilimsel Tıp Yayınevi; 2007. p. 44-56

12. Sipahi OR, Pullukçu $H$, Aydemir Ş, Taşbakan M, Tunger A, Arda $B$, et al. Resistance Patterns of Microbiologically Confirmed Nosocomial Bacteremia Related Staphylococcus aureus Strains: Evaluation of Results of 2001-2005 Periods. Ankem Derg 2007;21:1-4.

13. Dizbay M, Sipahi AB, Günal Ö, Kırca F, Şanal L, Çağlar K, et al. Investigation of Glycopeptid and Linezolid Resistance among Methicillin-Resistant Staphylococcus aureus Isolates. Ankem Derg 2007;21:23-6.

14. Derbentli Ş. Nozokomiyal enterokok infeksiyonları. Galenos 1998;23:14-7.

15. Maranan MC, Moreira B, Boyle-Vavra S, Daum RS. Antimicrobial resistance in staphylococci. Epidemiology, molecular mechanisms, and clinical relevance. Infect Dis Clin North Am 1997;11:813-49. [CrossRef]

16. Şengöz G, Yıldırım F, Kart Yaşar K, Şengöz A, Nazlıcan Ö. Resistance of Staphylococcus Strains against Fusidic Acil and Other Antibiotics. Ankem Derg 2004;18:105-8.

17. Doğan Ö, Yalınay Çırak M, Engin D, Türet S. Klinik örneklerden izole edilen stafilokoklarda metisilin direnci ve çeşitli antibiyotiklere in vitro duyarlılıkları. Ankem Derg 2005;19(1):39-42.

18. Gülhan B, Bilek H, Onur A, Gül K. Metisiline Dirençli Stafilokoklarda Linezolid, Vankomisin ve Bazı Antibiyotiklere Direnç. Ankem Derg 2007;21:214-8.

19. Rajaduraipandi K, Mani KR, Panneerselvam K, Mani M, Bhaskar $M$, Manikandan P. Prevalence and antimicrobial susceptibility pattern of methicillin resistant Staphylococcus aureus: a multicentre study. Indian J Med Microbiol 2006;24:34-8. [CrossRef]

20. Kanan B. Gram-Pozitif Bakterilere karşı in vitro Linezolid Aktivitesinin Değerlendirilmesi. Osmangazi Üniversitesi Tıp Fakültesi Mikrobiyoloji Anabilim Dalı. Uzmanlık Tezi. Eskişehir: 2002.

21. Sümerkan B. Vankomisine dirençli enterokoklar. In: Günaydın M, Esen Ş, Saniç A, Leblebicioğlu H, editors. Sterilizasyon Dezenfeksiyon ve Hastane İnfeksiyonları Samsun: Samsun İnfeksiyon Hastalıkları ve Klinik Mikrobiyoloji Araştırmaları
Derneği; 2002. p.329-34.

22. Çınar T, Leblebicioğlu H, Eroğlu C, Sünbül M, Esen Ş, Günaydın M. Enterokoklarda Penislin-Aminoglikozid Sinerjisinin Araştırılması. Klimik Dergisi 1999;12:39-42.

23. Aguş N, Sarıca A, Özkalay N, Cengiz A. Antimicrobial Resistance of Enterococcus Strains Isolated from Clinical Specimens. Ankem Derg 2006;20:145-7.

24. Louis B. Rice. Emergence of Vankomycin-Resistant Enterococci. CDC Emerging Infectious Disease 2001;7:183-7. [CrossRef]

25. Lundstrom TS, Sobel JD. Antibiotics for gram- positive bacterial infections: vancomycin, quinupristin-dalfopristin, linezolid, and daptomycin. Infect Dis Clin 2004;18:651-68. [CrossRef]

26. Jones RN, Ross JE, Fritsche TR, Sader HS. Oxazolidinone susceptibility patterns in 2004: report from the Zyvox Annual Appraisal of Potency and Spectrum (ZAAPS) Program assessing isolates from 16 nations. J Antimicrob Chemother 2006;57:279-87. [CrossRef]

27. Henwood CJ, Livermore DM, Johnson AP, James D, Warner M, Gardiner A. Gardiner and Linezolid Study Group. Susceptibility of Gram-positive cocci from 25 UK hospital to antimicrobial agents including linezolid. J Antimicrob Chemother 2000;46:931-40. [CrossRef]

28. Bozdoğan B, Appelbaum PC. Oxazolidinones: activity, mode of action, and mechanism of resistance. Int J Antimicrob Agents 2004;23:113-9. [CrossRef]

29. Ertem TG, Öztürk B, Ataman Hatipoğlu Ç, Ijpekkan K, Erdem F, Adiloğlu AK, et al. In Vitro Susceptibilities of Staphylococcus and Enterococcus Isolates to Linezolid, Daptomycin, Teicoplanin and Fusidic Acid. Turkiye Klinikleri J Med Sci 2013;33:1381-7. [CrossRef]

30. Ağalar C, Göçmen JS, Kılıç D, Kaygusuz S, Karabıçak Ç. Üçüncü basamak bir referans hastanesinde izole edilen metisilin dirençli stafilokok suşlarında duyarlılık. J Experiment Clin Med 2012;3:71-4.

31. Efe Ş, Sınırtaş M, Özakın C. In Vitro Susceptibility to Linezolid in Methicillin-Resistant Staphylococcus Aureus and VancomycinResistant Enterococcus Strains. Mikrobiyol Bul 2009;43:639-43.

32. Cesur S, Irmak H, Şimşek H, Çöplü N, Kılıç H, Arslan U, et al. Evaluation of Antibiotic Susceptibilities and VISA-VRSA Rates Among MRSA Strains Isolated from Hospitalized Patients in Intensive Care Units of Hospitals in Seven Provinces of Turkey. Mikrobiyol Bul 2012;46:352-8. 